\title{
Evaluation of some Modified Flood Irrigation Methods on Growth and Fruit Quality of Valencia Orange Trees under Sandy Soil Conditions
}

\author{
R.A. Abdel-Aziz, Fatma K., and M.A. Ibrahim \\ Citrus Research Department, Horticulture Research Institute, \\ Agriculture Research Centre, Cairo, Egypt.
}

\begin{abstract}
TIELD experiment was applied under sandy soil conditions to modify flood irrigation methods which are already used in numerous of citrus orchards aiming to save water consumption, increase irrigation efficiency and enlarge the potential wet area. It is established in an orchard of 5-year-old Valencia orange trees (Citrus sinensis) grafted on volkameriana lemon (Citrus volkameriana) located at Al-Adlia cooperative farms, Sharkia, Egypt. The treatments were; 1- Modified Blind Blocks (MBB), 2- Surrounding Square (SS), 3- Single Line (SL), 4- Comb Method (CM), 5- Single Railway (SR), 6- Double Railway (DR) and 7- Double Drip Lines (DDL). The studied parameters were; soil moisture content, tree root density, tree root horizontal extension and vertical penetration, tree canopy volume increment percentage, spring flush cycle and number of leafy inflorescences per shoot, fruit set percentage, fruit weight, fruit TSS and juice volume, theoretical yield and finally the water use efficiency (WUE). The obtained results showed that the modified irrigation methods which increase the water distribution efficiency and the potential wet area were DR, SR, CM SS and MBB; they successfully promoted all the studied parameters except the fruit TSS. While the SL and DDL methods that have less potential wet area around tree canopy resulted in less values. The results also showed that WUE in DR increased with about $38.9 \%$ in comparison with DDL.
\end{abstract}

Finally, from the economic point of view the DR irrigation method ranked as the first among all the others followed by SS.

Keywords: Irrigation, Water Use efficiency, Soil moisture, Roots .

Water is one of the most important inputs of the economic development. It is, also, known that the less the water resources are the more the demand is. In Egypt, the rainfall is rare and the desert covers most of the country area while the quota from the Nile River, represents the main source of water. This quota hasn't changed since 1959. In addition to the future threatened arise by building new dams over the Nile River and the increase in water exploitation to support population growth and resource development (Allam et al., 2005). 
Moreover, the quantity, quality of irrigation water and the wet area are varying depending on the water source, the rate of water flow and the irrigation methods.

Therefore, the better management of irrigation water has become more critical. The performance of water delivery systems, particularly irrigation systems, needs to be clearly defined and assessed under these current or expected stressed conditions.

In Egypt, irrigation systems are flood, drip, spray and subsurface irrigation. Flood irrigation has evolved into an extensive array of configurations which can be broadly classified as: basin; blocks; furrow irrigation; and uncontrolled flooding. Drip irrigation is considered the common irrigation system used in the newly reclaimed lands leading the water requirements for crop growth is greatly reduced. It has been used mainly under sandy soil conditions and it has the highest water use efficiency (WUE) among other irrigation systems.

On the other hand, drip irrigation system is committed with some problems such as; the higher energy consumption due to the higher number of operation hours, limitation of the wet area under tree canopy rather than the system maintenance which make it considered more costly than the flood one. In addition to the salt accumulation in the root zone which can, indeed, be a concern for farmers irrigating tree crops (Burt and Isbell, 2003). These problems have negative impact on tree vegetative growth, yield and the farmer net income. In contrast, flood irrigation has the greatest wet area but the lowest WUE. It is also a fact that as much as the wet area increased as much as the area explored with tree root system increased Levin et al. (1980) and Alkinson et al. (2000)

In this respect, José et al. (2012) decleared that the concentration of citrus fibrous roots, developed under drip-irrigated systems, is limited to the wetted soil around the emitters. Meanwhile, in the flood irrigation system, the roots are distributed in the whole wetted area around the tree canopy, thus reflecting its impact on the tree growth and yield Dariusz (1992).

The present investigation is aiming to develop and evaluate a number of compromising pressurized and flood irrigation methods to be adopted with the conditions of newly reclaimed lands, increase water use efficiency, reduce energy consumption and improve citrus tree growth and yield.

\section{Materials and Methods}

This study was carried out on sixty three 5-year-old Valencia orange (Citrus sinensis) trees grafted on Volkameriana lemon (Citrus volkameriana) rootstock planted at $6 \mathrm{~m} \times 4 \mathrm{~m}$ apart during three successive seasons. The data of the last two seasons 2012 and 2013 are only considered. The orchard is located in AlAdlia cooperative farms, Sharkia governorate, Egypt latitude $30^{\circ} 20^{\prime} 6.5^{\prime \prime} \mathrm{N}$ and longitude $31^{\circ} 35^{\prime} 24.8$ Ë in sandy clay loam soil.

Egypt. J. Hort. Vol. 40, No.2 (2013) 
The trees are of almost uniform vigor and received the customary practices for pruning, organic fertilization, etc. The recommended fertilization program was according to the Ministry of Agriculture fertilization program for citrus (1994).

Experimental design and statistical analysis: The complete randomize block design (CRBD) of seven treatments and three replicates were followed. Each experimental unit was represented by three trees. The treatments were; modified blind blocks (MBB), surrounding square (SS), single line (SL), comb method $(\mathrm{CM})$, single railway (SR), double railway (DR) and double drip lines (DDL) as a control (Fig. 1). The obtained data was statistically analyzed using the Statistical Analysis System (SASM-Agri). The effects were tested using the general Linear Model. A correlation between treatments and the tested parameters as well as a trend line were performed according to Croxton et al. (1968).

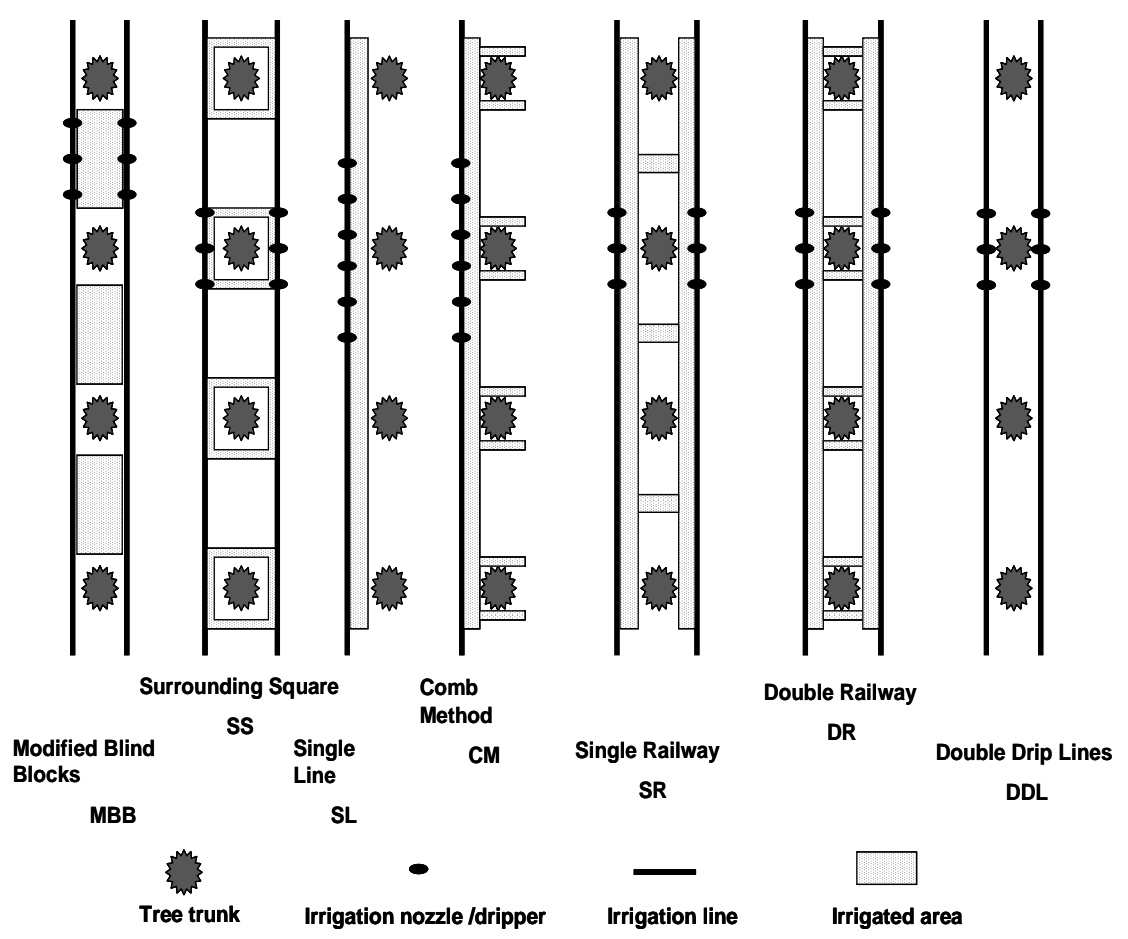

Fig. 1. The tested irrigation methods.

Establishment of the irrigation methods

Modified blind blocks (MBB): a blind block is established (1.5 x $1 \times 1 \mathrm{~m})$ between trees in the same row and the irrigation water is applied in the block area from 6 nozzles (20 liter/h) 0.5 meter apart; three nozzles per each irrigation line 
Surrounding square (SS): an irrigation canal (1.4 x $0.4 \times 4 \mathrm{~m})$ is established around each tree canopy forming a square edging the tree shadow. Two irrigation lines with 6 nozzles $(20$ liter/h), three per each and 0.5 meter apart to supply the irrigation water.

Single line $(S L)$ : an irrigation canal $(4 \times 0.4 \times 1 \mathrm{~m})$ is established a long with the tree row, the irrigation line is located inside this canal and 6 nozzles (20 liter/h), 0.5 meter apart, were settled.

Comb method (CM): an irrigation canal [ $(4 \times 0.4 \times 1 \mathrm{~m})+(1 \times 0.4 \times 2 \mathrm{~m})]$ is established a long with the tree row, other non-connected two vertical canals were established on both tree sides. The irrigation line is located inside these canals and six nozzles (20 liter/h), 0.5 meter apart, were settled.

Single railway $(S R)$ : two parallel longitudinal shallow irrigation canals [ $4 \mathrm{x}$ $0.4 \times 2 \mathrm{~m})+(1 \times 0.4 \times 1 \mathrm{~m})]$ is established and then one vertical canal is settled between each two trees, the irrigation tube with 6 nozzles (20 liter/h) 0.5 meter apart, is located in these canals

Double railway $(D R)$ : two parallel longitudinal shallow irrigation canals [ $(4 \mathrm{x}$ $0.4 \times 2 \mathrm{~m})+(1 \times 0.4 \times 2 \mathrm{~m})]$ is established and then two vertical canals are settled around each trees, the irrigation tube with 6 nozzles (20 liter/h) 0.5 meter apart, is located in these canals

Double drip lines (DDL): two irrigation lines with 6 emitters (4 liter/h and $0.4 \mathrm{~m}$ circle wet area radius) were settled for each tree.

Calculations of potential and actual wet area:

Table 1 shows the calculation of potential wet area in each experimental treatment according to each method dimensions (m) while the average of actual wet area $\left(\mathrm{m}^{2}\right)$ has been measured visually during the first season of the experiment.

TABLE 1. Calculations of potential and actual wet area: $\left(\mathrm{m}^{2}\right)$ of the tested irrigation methods .

\begin{tabular}{|c|c|c|c|c|}
\hline \multirow[t]{2}{*}{ Treatments } & \multicolumn{2}{|c|}{$\begin{array}{c}\text { Dimensions } \\
(\mathbf{m})\end{array}$} & \multicolumn{2}{|c|}{$\begin{array}{c}\text { Total wet area } \\
\left(\mathbf{m}^{2}\right)\end{array}$} \\
\hline & Length & Width & Potential & Av. actual \\
\hline MBB & 1.5 & 1 & 1.5 & 1.5 \\
\hline SS & 1.4 & 0.4 & 2.4 & $2.4<$ \\
\hline SL & 4.0 & 0.4 & 1.6 & $1.6 \leq$ \\
\hline \multirow[t]{2}{*}{$\mathrm{CM}$} & 4.0 & 0.4 & \multirow{2}{*}{2.4} & \multirow{2}{*}{$2.4>$} \\
\hline & 1.0 & 0.4 & & \\
\hline \multirow[t]{2}{*}{ SR } & 4.0 & 0.4 & \multirow{2}{*}{3.6} & \multirow{2}{*}{$3.6>$} \\
\hline & 1.0 & 0.4 & & \\
\hline \multirow[t]{2}{*}{ DR } & 4.0 & 0.4 & \multirow{2}{*}{4.0} & \multirow{2}{*}{$4<$} \\
\hline & 1.0 & 0.4 & & \\
\hline DDL & \multicolumn{2}{|c|}{$=\pi \times \mathrm{r}^{2 *}=1.14 \times(0.4)^{2}$} & 1.09 & 1.09 \\
\hline
\end{tabular}

Egypt. J. Hort. Vol. 40, No.2 (2013) 
Calculation of irrigation water quantity: The irrigation water quantity $\left(4725 \mathrm{~m}^{3} / \mathrm{fed} /\right.$ year) is theoretically calculated Table, 2 using site climatic data according to Radiation's equation (FAO, 1975 \& Doorenbos and Pruitt, 1977) as follow:

$\mathrm{ETo}=\mathrm{c}(\mathrm{W} . \mathrm{Rs})$ Where:

ETo: reference crop evapotranspiration ( $\mathrm{mm} /$ day) for the periods considered. $\mathrm{c}$ : adjustment factor depends on mean humidity and day time wind conditions. $\mathrm{W}$ : weighing factor depends on temperature and altitude.

Rs: solar radiation in equivalence

TABLE 2. Calculations of the theoretical monthly water requirements according to Radiation's equation .

\begin{tabular}{|c|c|c|c|c|c|c|c|c|c|c|c|c|}
\hline $\begin{array}{c}\text { Water } \\
\text { Requirements } \\
\text { (WR) }\end{array}$ & Jan & Feb & Mar & Apr & May & Jun & Jul & Aug & Sep & Oct & Nov & Dec \\
\hline Eto & 2.9 & 3.5 & 4.4 & 6.8 & 7.8 & 8.9 & 9.5 & 7.5 & 6.8 & 6.0 & 4.2 & 4.0 \\
\hline Ke & 0.61 & 0.64 & 0.67 & 0.72 & 0.78 & 0.81 & 0.8 & 0.79 & 0.46 & 0.58 & 0.64 & 0.58 \\
\hline $\mathrm{WR} \mathrm{mm} / \mathrm{m}^{2} /$ day & 1.77 & 2.24 & 2.95 & 4.90 & 6.08 & 7.21 & 7.60 & 5.93 & 3.13 & 3.48 & 2.69 & 2.32 \\
\hline WR mfed/day & 7.4 & 9.4 & 12.4 & 20.6 & 25.6 & 30.3 & 31.9 & 24.9 & 13.1 & 14.6 & 11.3 & 9.7 \\
\hline Intervals & 10 & 10 & 15 & 15 & 30 & 30 & 30 & 30 & 15 & 15 & 15 & 10 \\
\hline WRm/fed/month & 74.30 & 94.08 & 185.72 & 308.45 & 766.58 & 908.33 & 957.60 & 746.55 & 197.06 & 219.24 & 169.34 & 97.44 \\
\hline
\end{tabular}

All trees have received the same amount of irrigation water using the different tested irrigation methods. More details are shown in Table 3.

TABLE 3. Illustration of water quantity distribution according to nozzle or drippers and/or discharge and working hours per fed/year $/ \mathrm{m}^{3}$.

\begin{tabular}{|c|c|c|c|c|c|c|}
\hline $\begin{array}{c}\text { No. } \text { / } \\
\text { Tree }\end{array}$ & Types & $\begin{array}{c}\text { Discharge } \\
(\mathbf{L} / \mathbf{h})\end{array}$ & $\begin{array}{c}\text { No. of } \\
\text { irrigation } \\
\text { intervals/ } \\
\text { year/tree }\end{array}$ & $\begin{array}{c}\text { Water } \\
\text { quantity / } \\
\text { tree/L/ } \\
\text { year }\end{array}$ & $\begin{array}{c}\text { Daily } \\
\text { operation } \\
\text { hours/ } \\
\text { day }\end{array}$ & $\begin{array}{c}\text { Water } \\
\text { quantity } \\
\left(\mathbf{m}^{\mathbf{3}} / \mathbf{f e d} /\right. \\
\text { Year)* }\end{array}$ \\
\hline 6 & Nozzel & 20 & 225 & 27000 & 1 & 4725 \\
\hline 6 & Drippers & 4 & 225 & 5400 & 5 & 4725 \\
\hline
\end{tabular}

Soil samples: before starting the experiment a harmonized soil sample was taken and the main soil physical properties of the experimental orchard were shown in Table 4. During the experiment, soil samples were collected at 0-60 cm depths with the aid of a $3.5 \mathrm{~cm}$ diameter soil auger. Twelve auger points were taken along the diagonals of each plot. Homogenized and composite samples were analyzed. The following soil parameters were measured. 
TABLE 4. Main physical properties of the soil under experimental trees .

\begin{tabular}{|c|c|c|c|c|c|c|c|c|c|}
\hline \multirow{2}{*}{$\begin{array}{c}\text { Depth } \\
\text { (cm) }\end{array}$} & \multicolumn{3}{|c|}{\begin{tabular}{c}
\multicolumn{2}{|c|}{ Particle size distribution } \\
$(\%)$
\end{tabular}} & \multicolumn{3}{|c|}{$\begin{array}{c}\text { Total } \\
\text { porosity } \\
\text { (\%) }\end{array}$} & \multicolumn{4}{|c|}{ Moisture content (\%) } \\
\cline { 2 - 9 } & $\begin{array}{c}\text { Coarse } \\
\text { sand }\end{array}$ & $\begin{array}{c}\text { Fine } \\
\text { sand }\end{array}$ & Silt & Clay & & $\begin{array}{c}\text { Saturation } \\
\text { point (S.P.) }\end{array}$ & $\begin{array}{c}\text { Field } \\
\text { capacity } \\
\text { (F. C.) }\end{array}$ & $\begin{array}{c}\text { Available } \\
\text { water } \\
\text { (Av. W.) }\end{array}$ & $\begin{array}{c}\text { Wilting } \\
\text { Point } \\
\text { (W.P.) }\end{array}$ \\
\hline $0-60$ & 61.25 & 25.50 & 3.26 & 9.99 & 39.99 & 18.60 & 10.00 & 4.20 & 2.50 \\
\hline
\end{tabular}

* According to the particle size distribution (\%), the experimental soil is classified as sandy clay loam.

\section{Soil moisture contents}

The fresh weight samples $(\mathrm{g})$ were recorded then dried at $105 \mathrm{C}^{\circ}$ till constant weight. Then, the average soil moisture content $(\%)$ was calculated as follows:

Soil moisture $(\%)=$ SFW $(g)-$ SDW / SDW x 100

Where: SFW: Soil fresh weight (g) - SDW: Soil dry weight (g)

The level of soil moisture was considered high (>8\%), intermediate (4.2- $8 \%$ ) and low $(<4.2 \%)$ according to the American Soil Taxonomy, (1975).

\section{Tree measurements}

Tree root density $\left(\mathrm{g} / \mathrm{cm}^{3}\right.$ soil)

At the end of the second season, root density (total weight of fibrous roots ( $g$ ) in a constant amount of soil sample, expressed as roots weight $/ \mathrm{cm}^{3}$ of soil) was calculated in this study. Root density was measured in the same abovementioned sites of soil samples. The average root density was determined in a harmonized soil sample as described by Newman (1966).

\section{Horizontal root extension and vertical root penetration $(m)$}

The maximum vertical root penetration in soil at $100 \mathrm{~cm}$ from tree trunk was determined. The maximum horizontal root extension from tree trunk (average of the four tree directions) was measured and expressed in (meter).

Tree canopy volume increments percentage

At the beginning and at the end of each season of the experiment the tree canopy volume $\left(\mathrm{m}^{3}\right)$ was calculated according to the equation: Canopy volume $\left(\mathrm{m}^{3}\right)=$ $0.5236 \mathrm{x}$ height $\mathrm{x}$ diameter square as stated by Turell, 1965. The yearly increments percentage in tree canopy volume was calculated $=[(\mathrm{TCV} 2-$ TCV1)/TCV1] x 100 where TCV1: the tree canopy volume in the beginning, TCV2 the tree canopy volume at the end $\left(\mathrm{m}^{3}\right)$.

Spring flush cycle and leafy inflorescences: a woody squire (1 x $1 \mathrm{~m})$ was used each season to count spring flush cycle and leafy inflorescences in the four directions of the tree crown and the average was calculated. 
Fruit set (\%): Thirty new shoots were labeled around each experimental tree; the number of flowers on each labeled shoot was counted on the bloom reached open flower stage. Later on, the numbers of set fruitlets were counted on the same tagged shoots. Fruit set percentage was calculated [(number of set fruitlets) /number of flowers x 100].

Fruit weight $(\mathrm{g})$ : Thirty fruits were randomly collected at time of harvest from each tree; the fruit weight $(\mathrm{g})$ was measured.

Fruit TSS and juice volume $\left(\mathrm{cm}^{3}\right)$ : At time of harvesting, the extracted juice was used to determine total soluble solids percent (TSS) using hand refractometer and the extracted juice of each fruit $\left(\mathrm{cm}^{3}\right)$ was measured.

Yield/ton/fed.: At the end of each experimental season, the number of fruit per tree was counted then a sample of 10 fruits was weighted and the average fruit weight was taken as well as fruit volume $\left(\mathrm{cm}^{3}\right)$. The yield per ton/fed. was theoretically calculated as follows $=$ [average fruit weight $(\mathrm{g}) \mathrm{x}$ number of fruit/tree $\mathrm{x}$ number of trees/fed.]/1000

Water use efficiency (WUE): At the end of each experimental season, water use efficiency was calculated using the equation: Yield $(\mathrm{kg}) / \mathrm{Irrigation}$ water quantity $\left(\mathrm{m}^{3}\right)$.

\section{Results and Disscusion}

\section{Soil moisture \%}

Fig. 2 shows the soil moisture $\%$ in the two experimental seasons, as well as the linear correlation between soil moisture and the potential wet area resulted from the tested irrigation methods. The results showed that DR, SS and SR have the highest values of soil moisture 11.8, 10.2, 9.2 \% and 13,11, $9.7 \%$ in both first and second season, respectively. However, the lowest value resulted from SL treatment in both seasons. Moreover, the results showed positive correlations between all modified irrigation methods and/ or the potential wet area and the soil moisture \%.

In general, none of the used irrigation methods resulted in lower level of soil moisture $(<4.2 \%)$ and the majority of those tested methods showed moderate level (4.2- 8\%) while DR, SS and SR commitments with the highest level (>8 \%) according to American soil taxonomy (1975).

In this respect, Troeh et al. (2004) mentioned that the soil moisture content is in proportional relationship with the soil wet area. 


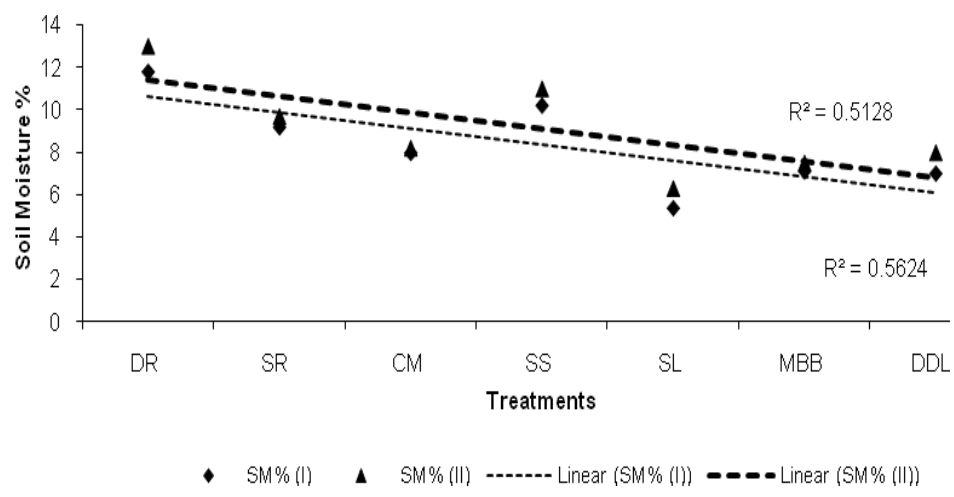

Fig. 2. Soil moisture content $(\%)$ as affected by the different modified irrigation methods on Valencia orange trees in both experimental seasons.

Tree measurements

Tree root density $\left(\mathrm{g} / \mathrm{cm}^{3}\right.$ soil)

The results in Fig. 3 indicated that the differences between all tested treatments were significant. The highest values were obtained from the DR and SS irrigation methods followed by MBB without significant differences while the lowest values were resulted from the use of DDL irrigation method. A positive correlation is also found between the potential wet area (irrigation water distribution methods) and the root density. It is noticed that as much as the irrigation water penetrate large soil area, within the field capacity, as much as the root growth improved and consequently the values of root density increased. This fact was clear with the DR and SS irrigation methods. In this respect, Eissenstat et al. (1999) found that root density is directly proportional to soil moisture or irrigation practices.

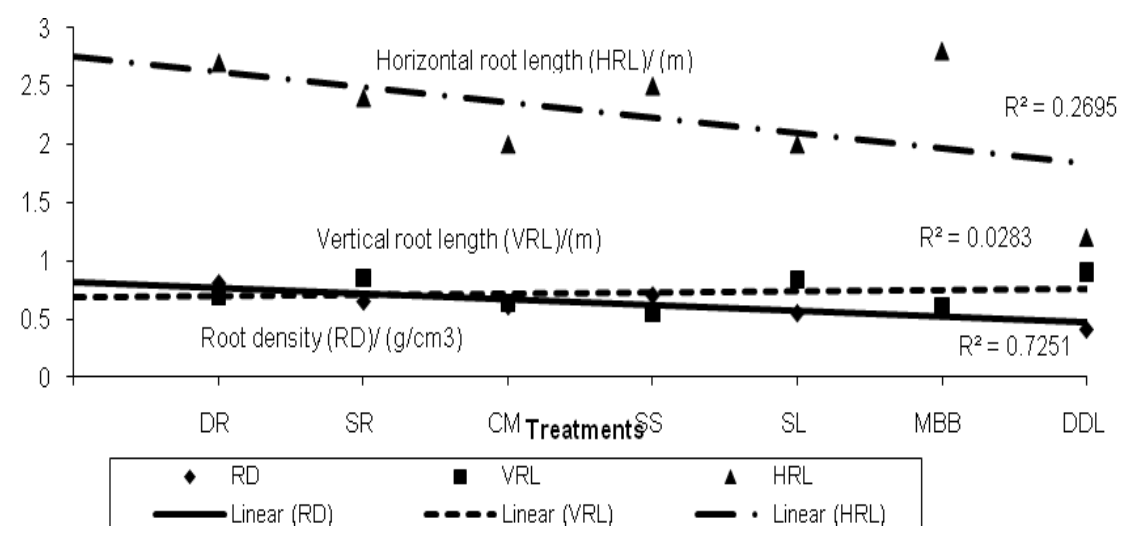

Fig. 3. The root density $\left(\mathrm{g} / \mathrm{cm}^{3}\right.$ soil), the root vertical and horizontal distribution $(\mathrm{m})$ on Valencia orange trees in the second experimental season.

Egypt. J. Hort. Vol. 40, No.2 (2013) 


\section{Root horizontal and vertical distribution}

Data in Fig. 3 also shown that the highest values of root horizontal distribution $(2.8,2.7,2.5$ and $2.4 \mathrm{~m})$ were committed with MBB, DR, SS and SR while the lowest values $(1.2,2$ and $2 \mathrm{~m}$ ) were obtained from the use of DDL, SL and CM irrigation methods, respectively. Also, there were positive correlation between the root distributions horizontally and the potential wet area. This was clear since the results showed that the larger the wetted area the higher the root grows horizontally seeking for irrigation water and/or soil moisture.

As for the vertical root distribution, the results in Fig. 3 showed significant differences between all treatments. A positive correlation was observed between the irrigation methods (potential wet area) and the vertical root distribution. However, the results of vertical root distribution were inversely proportional with the horizontal ones. The highest values $(0.9,0.85$ and $0.84 \mathrm{~m})$ were resulted from the use of DDL, SR and SL while the lowest values $(0.55$ and $0.6 \mathrm{~m})$ obtained from the use of SS and MBB irrigation methods. The DR and CM resulted in moderate values $(0.7$ and 0.64 $\mathrm{m})$. This is true since the tree root grow deeper to explore more soil moisture particularly when the irrigation method doesn't scope high wetted area. Moreover, root development can also be restricted by a low availability of water and nutrients (Kramer and Boyer, 1995). The obtained results are in line with those mentioned by (Kelly et at., 2007).

Tree canopy volume increments percentage

Table 5 shows the results of tree volume increments percentage in both experimental seasons. The results indicated that DR, SS and SR gave the highest results while DDL, SL, MBB and CM were the lowest. It is well-known that the vegetative tree volume is a final result of the vegetative growth including tree height and diameter (Turell, 1965). The DR, SS and SR resulted in higher potential wetzone which cause more root distribution (data was previously mentioned in Fig. 3) and consequently more water and nutritional absorption. Moreover, the statistical analysis shows positive correlation $\left(\mathrm{R}^{2}=0.0137\right)$ between the averages of the absolute values of the tree volume increments $(\mathrm{m})$ in both seasons and the potential wet area or the irrigation methods. Several studies showed that tree size was related to root density and/or distribution in the deep sandy soils and irrigation practices. (Castle \& Krezdorn, 1975 and Ford, 1968, 1969, 1972).

TABLE 5. Tree volume increments $(\%)$ as affected by the tested irrigation methods on Valencia orange trees in both experimental seasons.

\begin{tabular}{|l|c|c|c|}
\hline $\begin{array}{c}\text { Irrigation } \\
\text { Methods }\end{array}$ & $\begin{array}{c}\text { Tree volume } \\
\text { increments (\%) } \\
(\mathbf{2 0 1 2} \text { season) }\end{array}$ & $\begin{array}{c}\text { Tree volume } \\
\text { increments (\%) } \\
(\mathbf{2 0 1 3} \text { season) }\end{array}$ & Average (\%) \\
\hline DR & $45 \mathrm{a}$ & $50 \mathrm{a}$ & 47.5 \\
\hline SR & $36 \mathrm{ab}$ & $40 \mathrm{ab}$ & 38.0 \\
\hline CM & $30 \mathrm{~b}$ & $35 \mathrm{~b}$ & 32.5 \\
\hline SS & $40 \mathrm{a}$ & $45 \mathrm{a}$ & 42.5 \\
\hline SL & $25 \mathrm{~b}$ & $30 \mathrm{~b}$ & 27.5 \\
\hline MBB & $28 \mathrm{~b}$ & $30 \mathrm{~b}$ & 29.0 \\
\hline DDL & $14 \mathrm{c}$ & $20 \mathrm{c}$ & 17.0 \\
\hline
\end{tabular}

Spring flush cycle (shoots $/ 0.50 \mathrm{~cm}^{2}$ ) and leafy inflorescences (number/shoot). 
Figure 4 and Fig. 5 demonstrate the results of spring flush cycle density (SFCD) and leafy inflorescences in both experimental seasons. The lowest values were resulted from the use of DDL, SL and MBB irrigation methods. In this respect, it is noticed that DDL resulted in the lowest value (2.0 and 2.0 shoots $/ 50 \mathrm{~cm}^{2}$ ) in both seasons. The DR, SR, SS and CM resulted in the highest values $\left(8.0,6.0,6.0,6.0\right.$ shoots $\left./ 50 \mathrm{~cm}^{2}\right)$ without significant differences among treatments in the first season while the differences were significant in the second season $\left(10.0,8.0,8.0\right.$ and 5.0 shoots $\left.50 \mathrm{~cm}^{2}\right)$. However, $\mathrm{SL}$ and $\mathrm{CM}$ resulted in intermediate values of SFCD $\left(3.0,4.0\right.$ and $2.0,3.0$ shoots/ $\left.50 \mathrm{~cm}^{2}\right)$ in the first and second season, respectively.

It is also noticed that the values of SFCD for SS, SR and DR irrigation methods were higher in the second season than these ones in the first season. Whereas, the opposite situation was clear in the CM, MBB and SL irrigation methods. This can be due to in the DR, SR and SS the trees received the required irrigation water easily since the irrigation water is well distributed around the tree canopy and the potential wet area is higher. In this respect, Carr (2012) declared that shoot growth and elongation occurs when the irrigation water is available. Labanauskas et al. (1966) on orange seedlings, pointed out that moisture content of the soil influenced nutrients uptake, translocation, and distribution within citrus plants, and that might contribute to vegetative flushes.

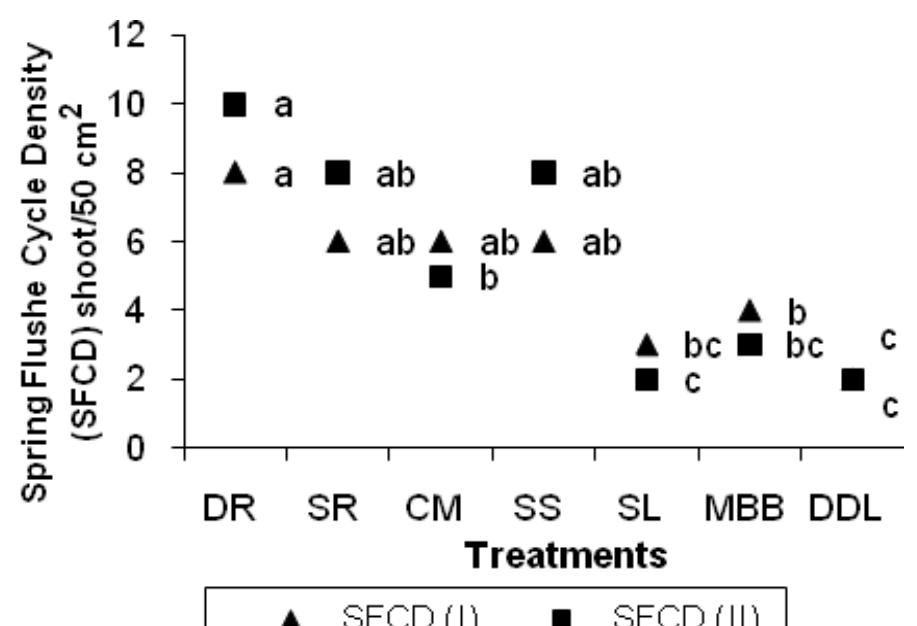

Fig. 4. The spring flush cycle as affected by the tested treatments on Valencia orange trees in both experimental seasons . 


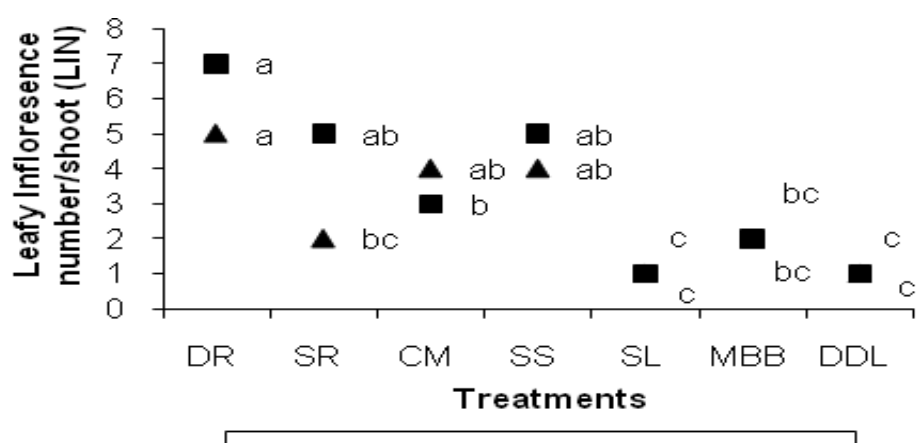

Fig. 5. Leafy inflorescences as affected by the tested treatments on Valencia orange trees in both experimental seasons .

However, the reduction in growth rate under higher soil moisture level might be due to lack of soil air necessary to root growth and the life of microorganisms El-Kassas (1972).

On the other hand, the majority of the spring flush cycle was classified as leafy inflorescence. The results of leafy inflorescences (no./shoot) indicated that the higher values were significantly obtained from the use of DR, SS, CM and SR irrigation methods. The highest values were committed with DR (5.0 and 7.0 leafy inflorescences/shoot) in the first and second season, respectively. The CM and $\mathrm{MBB}$ were intermediate. However, the lowest values were on leafy inflorescences/shoot with DDL and SL tested irrigation methods.

Generally, all the irrigation methods which increase soil moisture contents contribute to the formation of citrus inflorescences. In this respect, Lenz, 1966 stated that the type of citrus inflorescences depends on the temperature, soil moisture and tree nutritional status.

\section{Fruit set (\%)}

Figure 6 shows that the differences among treatments concerning the results of fruit set \% were significant. DR, SS and CM significantly resulted in the highest values followed by SR, MBB and SL irrigation methods. Meanwhile, the lowest value of fruit set resulted when the DDL irrigation method was used. The same trend observed in both experimental seasons. In this concern, it is well known that as much as the irrigation method is providing not only sufficient water and maintaining soil moisture contents but also a well distributing and increasing in root wet-zone, as much as it is positively reflected on fruit set percentage Legas et al. (1981). Moreover, these results are compatible with the results of tree leafy inflorescence number previously showed in Fig. 5, which can be due to the important role of leaves in supplementing carbohydrates and other assimilated materials through the photosynthesis process (Moss et al., 1972 and Erner \& Bravdo, 1983) . 


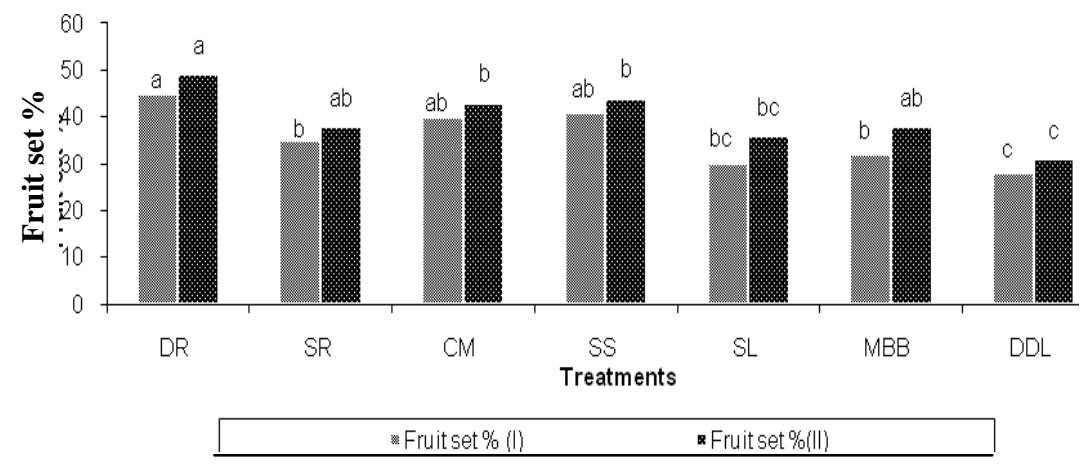

Fig. 6. Fruit set $(\%)$ as affected by the tested irrigation treatments on Valencia orange trees in both experimental seasons .

Fruit weight $(g)$ : The obtained data showed that DR, SS, SR and CM significantly resulted in the highest values of fruit weight and fruit number while MBB, SL and DDL resulted in the lowest values in both the experimental seasons. It seems that the low number of fruits produced in DDL, SL and MBB irrigation methods is owed to low tree canopy volume (Table 5). This was also observed for DR, SS, and SR; these trees showed almost the largest crown volumes. There is, therefore, a compatible effect between vegetative growth and fruit production. Some authors (Eliades, 1992 and Chartzoulakis et al., 1999) reported that irrigation increases the number of fruits produced, although Wiegand \& Swanson (1982a) and Castel \& Buj (1993) reported no important effect in this respect. The results obtained confirm reports made by others such as (García Petillo, 1995) who mentioned that fruit weight is the production component most affected by irrigation.

Fruit TSS (\%) and juice volume $\left(\mathrm{cm}^{3}\right)$ : The obtained data of fruit TSS showed inversely trend where the highest values resulted when DDL, SL and MBB while the lowest values were obtained with the use of CM, SR, SS and DR irrigation methods. It is noticed that fruit TSS increase when the absorbed irrigation water decreased. These results indicated that the DR, SS and SR are irrigation methods that provide sufficient water to the tree while DDL and/or the single side irrigation methods was the lowest irrigation methods in terms of providing sufficient potential wet area and irrigation water. In this respect, Navarro et al. (2010) argued that a moderate water-stress (from the irrigation methods that provide less wet zone under tree canopy) induced higher carbohydrates and total soluble solids concentration in juice than unstressed trees; and this fact was independent of fruit juice content. Moreover, they stated that the irrigation methods that ensure full irrigation water to citrus trees could promote a delay in maturation process. Concerning the fruit juice volume, the data showed that the highest fruit juice volume contents is commitment with SS, SR and CM irrigation methods, while the results were gradually decreased with MBB, DR, Egypt. J. Hort. Vol. 40, No.2 (2013) 
SL and DDL irrigation methods in the first season. The same trend was obtained in the second season. These results are in line with the results of fruit weight where the fruit juice volume increases when the fruit weight increases. However, the DR irrigation method showed opposite trend which can be due to the increase in fruit peel thickness instead of fruit pulp.

Yield /fed.: Data in Table 6 indicated that DR, SS and SR significantly induced the theoretical yield/fed. While the yield values are gradually decreased due to the use of CM, MBB and SL irrigation methods. The DDL resulted in the lowest yield values among all treatments. The results showed that yield/ton/fed. is proportionally directed with the irrigation methods that induce the potential wet area around the tree canopy. It is also correlated with fruit weight and fruit number. In the same time, the yield is positively correlated with the tree canopy volume as well as the root distributions that are previously discussed in Table 5 and Fig 3.

TABLE 6. Fruit weight (g), fruit number, juice volume $\left(\mathrm{cm}^{3}\right)$, TSS $(\%)$ and yield (ton/fed.) as affected by the tested irrigation methods on Valencia orange trees in both experimental seasons .

\begin{tabular}{|c|c|c|c|c|c|}
\hline Treatments & $\begin{array}{c}\text { Fruit } \\
\text { weight } \\
\text { (g) }\end{array}$ & $\begin{array}{c}\text { Fruit } \\
\text { number }\end{array}$ & $\begin{array}{c}\text { Juice } \\
\text { volume } \\
\left(\mathrm{cm}^{3}\right)\end{array}$ & $\begin{array}{c}\text { Fruit TSS } \\
(\%)\end{array}$ & $\begin{array}{c}\text { Yield } \\
\text { (ton/fed.) }\end{array}$ \\
\hline \multicolumn{6}{|c|}{ First season } \\
\hline DR & $175.5 \mathrm{a}$ & $284 \mathrm{a}$ & $64.4 \mathrm{~b}$ & $11.00 \mathrm{c}$ & $8.72 \mathrm{a}$ \\
\hline SR & $163.3 \mathrm{ab}$ & $265 \mathrm{a}$ & $72.0 \mathrm{a}$ & $11.50 \mathrm{~b}$ & $7.57 \mathrm{a}$ \\
\hline $\mathbf{C M}$ & $160.2 \mathrm{ab}$ & $246 \mathrm{ab}$ & $68.0 \mathrm{ab}$ & $12.00 \mathrm{~b}$ & $6.90 \mathrm{~b}$ \\
\hline SS & $173.2 \mathrm{a}$ & $277 \mathrm{a}$ & $75.0 \mathrm{a}$ & $11.20 \mathrm{c}$ & $8.40 \mathrm{a}$ \\
\hline SL & $148.4 \mathrm{~b}$ & $221 \mathrm{~b}$ & $60.0 \mathrm{~b}$ & $12.80 \mathrm{a}$ & $5.74 \mathrm{c}$ \\
\hline MBB & $155.3 \mathrm{~b}$ & $242 \mathrm{ab}$ & $66.5 \mathrm{~b}$ & $12.50 \mathrm{ab}$ & $6.58 \mathrm{~b}$ \\
\hline DDL & $140.4 \mathrm{c}$ & $218 \mathrm{~b}$ & $50.0 \mathrm{c}$ & $13.20 \mathrm{a}$ & $5.35 \mathrm{c}$ \\
\hline$* \mathbf{R}^{2}$ & 0.6 & 0.6375 & 0.338 & 0.7488 & 0.6448 \\
\hline \multicolumn{6}{|c|}{ Second season } \\
\hline DR & $180.0 \mathrm{a}$ & $290 \mathrm{a}$ & $100.5 \mathrm{a}$ & $10.50 \mathrm{c}$ & $9.14 \mathrm{a}$ \\
\hline SR & $165.0 \mathrm{ab}$ & $270 \mathrm{~b}$ & $78.0 \mathrm{~b}$ & $11.70 \mathrm{c}$ & $7.80 \mathrm{ab}$ \\
\hline $\mathbf{C M}$ & $165.0 \mathrm{ab}$ & $255 \mathrm{~b}$ & $75.0 \mathrm{~b}$ & $12.30 \mathrm{~b}$ & $7.36 \mathrm{ab}$ \\
\hline SS & $175.0 \mathrm{a}$ & $282 \mathrm{a}$ & $80.0 \mathrm{~b}$ & $10.60 \mathrm{c}$ & $8.64 \mathrm{a}$ \\
\hline SL & $155.0 \mathrm{~b}$ & $230 \mathrm{c}$ & $61.0 \mathrm{c}$ & $13.00 \mathrm{a}$ & $6.24 \mathrm{c}$ \\
\hline MBB & $160.0 \mathrm{~b}$ & $248 \mathrm{~b}$ & $71.0 \mathrm{~b}$ & $12.80 \mathrm{~b}$ & $6.94 \mathrm{~b}$ \\
\hline DDL & $145.0 \mathrm{c}$ & $220 \mathrm{c}$ & $55.0 \mathrm{c}$ & $13.70 \mathrm{a}$ & $5.58 \mathrm{c}$ \\
\hline$* \mathbf{R}^{2}$ & 0.668 & 0.6841 & 0.747 & 0.6292 & 0.6798 \\
\hline
\end{tabular}

$\mathrm{R}^{2}$ : Linear correlation between parameters and the tested potential wet area and/or irrigation methods

Water use efficiency (WUE)

Figure 7 shows the water use efficiency (WUE) as well as the linear trend lines of the tested irrigation methods in both seasons. The differences among all the tested treatments were significant. The data indicated that DR, SS and SR irrigation methods resulted in the highest values of WUE followed by CM and 
MBB without significant differences while the lowest value resulted from the SL and DDL irrigation method without significant differences. Moreover, the DR irrigation method increased WUE by 38.6 and $38.9 \%$ compared to the DDL irrigation method in both seasons, respectively. In this respect, Ray and Sharma (1990) stated that the crop water use efficiency incresaes as the frequiency of irrigation water increase.

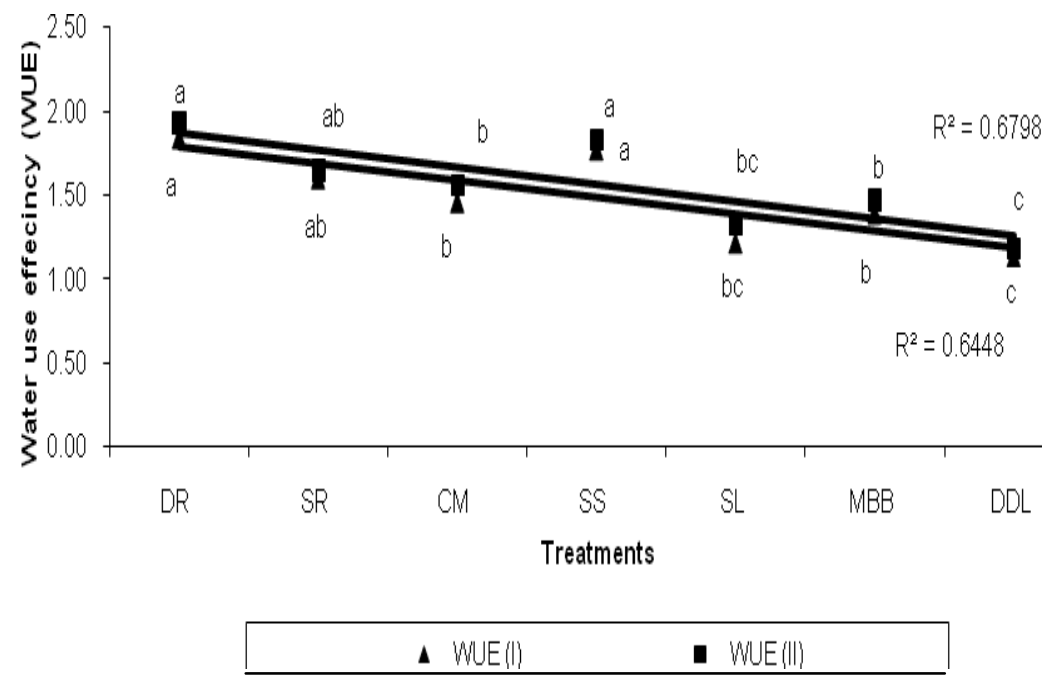

Fig. 7. Water Use Efficiency (WUE $\left(\mathrm{kg} / \mathrm{m}^{3}\right.$ irrigation water) and the linear trend lines as affected by the tested irrigation methods on Valencia orange trees in both experimental seasons.

\section{Economical viable}

Data in Tables 7, 8 and 9 indicated the total cost of establishment of the modified irrigation methods as well as the energy consumption needed for each one. The data showed that the cost of MBB was the highest followed by SS and DR irrigation methods with theoretical yield 6.76, 8.52 and 8.93 ton/fed. The SR and DDL were in the intermediate positions in terms of total yearly cost/fed. and yielded 7.69 and 5.47 ton/fed, while the CM and SL resulted in the less cost amongst all with yield/ton/fed 7.13 and 5.99, respectively.

Accordingly, the best economic irrigation method in term of net profit/fed [Total prfet/fed (LE) - Total yearly irrigation method cost/fed (LE)] was DR with 10465 (LE) followed by SS 9940 (LE) and SR with 8947 (LE). For both the two irrigation methods (SR and CM) they ranked not far off each other with net profit/fed 8947 and 8452 (LE), respectively. On the other hand, MBB, SL and DDL positioned in the last order with values of 7713, 7066 and 6237 (LE), respectively. 
EVALUATION OF SOME MODIFIED FLOOD IRRIGATION METHODS ... 241

TABLE 7. Irrigation laterals and drippers establishment cost/fed.

\begin{tabular}{|l|c|c|c|c|c|c|c|}
\hline $\begin{array}{c}\text { Irrigation } \\
\text { Methods }\end{array}$ & $\begin{array}{c}\text { length of } \\
\text { laterals/tree } \\
(\mathbf{m})\end{array}$ & $\begin{array}{c}\text { cost of } \\
\text { lateral } \\
(\mathbf{L E} / \mathbf{m})\end{array}$ & $\begin{array}{c}\text { Total } \\
\text { cost of } \\
\text { laterals } \\
\text { /tree } \\
(\mathbf{L E})\end{array}$ & $\begin{array}{c}\text { No of } \\
\text { drippers } \\
\text { /tree }\end{array}$ & $\begin{array}{c}\text { Cost } \\
(\mathbf{L E})\end{array}$ & $\begin{array}{c}* \text { Total } \\
\text { cost/fed } \\
(\mathbf{L E})\end{array}$ & $\begin{array}{c}\text { Yearly } \\
\text { cost/fed } \\
(\mathbf{L E})\end{array}$ \\
\hline DR & 8 & 0.85 & 7 & 6 & 2.70 & 1663 & 554.33 \\
\hline SR & 8 & 0.85 & 7 & 6 & 2.70 & 1663 & 554.33 \\
\hline CM & 4 & 0.85 & 3 & 6 & 2.70 & 1068 & 356.00 \\
\hline SS & 8 & 0.85 & 7 & 6 & 2.70 & 1663 & 554.33 \\
\hline SL & 4 & 0.85 & 3 & 6 & 2.70 & 1068 & 356.00 \\
\hline MBB & 8 & 0.85 & 7 & 6 & 2.70 & 1663 & 554.33 \\
\hline DDL & 8 & 0.85 & 7 & 6 & 2.70 & 1663 & 554.33 \\
\hline
\end{tabular}

Dripper price (LE) $\quad 0.45$

TABLE 8. Cost of labor, machines and energy consumption/day/fed.

\begin{tabular}{|c|c|c|c|c|c|c|c|c|c|c|c|c|}
\hline \multirow{3}{*}{$\begin{array}{l}\text { Irrigation } \\
\text { Methods }\end{array}$} & \multirow{2}{*}{\multicolumn{2}{|c|}{$\begin{array}{c}\text { Labors } \\
\text { cost/fed } \\
\text { (LE) }\end{array}$}} & \multicolumn{5}{|c|}{ Establishment cost (LE) } & \multirow{2}{*}{\multicolumn{3}{|c|}{$\begin{array}{c}\text { Two years } \\
\text { maintenance cost } \\
\text { (LE) }\end{array}$}} & \multirow{3}{*}{$\begin{array}{c}\text { Total } \\
\text { cost/fed } \\
\text { (LE) } \\
\text { (For } 3 \\
\text { years) }\end{array}$} & \multirow{3}{*}{$\begin{array}{c}\text { Yearly } \\
\text { cost/fed } \\
(\mathrm{LE})\end{array}$} \\
\hline & & & \multicolumn{2}{|c|}{$\begin{array}{c}\text { Machine } \\
\text { cost } \\
\text { (LE) }\end{array}$} & \multicolumn{3}{|c|}{$\begin{array}{c}\text { Energy } \\
\text { consumption } \\
\text { cost/hour (LE) }\end{array}$} & & & & & \\
\hline & $\begin{array}{l}\text { No. of } \\
\text { labors }\end{array}$ & $\begin{array}{l}\text { Cost } \\
\text { (LE) }\end{array}$ & $\begin{array}{c}\text { No of } \\
\text { working } \\
\text { days }\end{array}$ & $\begin{array}{l}\text { Cost } \\
\text { (LE) }\end{array}$ & $\begin{array}{c}\text { Working } \\
\text { hours }\end{array}$ & $\begin{array}{l}\text { Cost of } \\
\text { irrig.h }\end{array}$ & $\begin{array}{l}\text { Cost } \\
\text { (LE) }\end{array}$ & $\begin{array}{l}\text { No. of } \\
\text { labors }\end{array}$ & $\begin{array}{c}\text { years } \\
\text { No. }\end{array}$ & $\begin{array}{l}\text { Cost } \\
\text { (LE) }\end{array}$ & & \\
\hline DR & 3 & 210 & 1 & 80 & 1 & 0.5 & 0.5 & 1.00 & 2 & 140.00 & 430.50 & 143.50 \\
\hline SR & 2 & 140 & 1 & 80 & 1 & 0.5 & 0.5 & 0.67 & 2 & 93.33 & 313.83 & 104.61 \\
\hline $\mathrm{CM}$ & 2 & 140 & 1 & 80 & 1 & 0.5 & 0.5 & 0.67 & 2 & 93.33 & 313.83 & 104.61 \\
\hline SS & 4 & 280 & 0 & 0 & 1 & 0.5 & 0.5 & 1.33 & 2 & 186.67 & 467.17 & 155.72 \\
\hline SL & 1 & 70 & 1 & 80 & 1 & 0.5 & 0.5 & 0.33 & 2 & 46.67 & 197.17 & 65.72 \\
\hline MBB & 4 & 280 & 1 & 80 & 1 & 0.5 & 0.5 & 1.33 & 2 & 186.67 & 547.17 & 182.39 \\
\hline DDL & 1 & 70 & 0 & 0 & 5 & 0.5 & 2.5 & 0.33 & 2 & 46.67 & 119.17 & 39.72 \\
\hline Labor cost/da & (LE): & & & & 70 & & & & & & & \\
\hline Machine cost/ & fed/day ( & E): & & & 80 & & & & & & & \\
\hline Cost of energy & ne hol & rigat & tion/fed (L & & 0.5 & & & & & & & \\
\hline
\end{tabular}


TABLE 9. Irrigation treatments cost and yield profit estimation.

\begin{tabular}{|l|c|c|c|c|c|c|}
\hline $\begin{array}{c}\text { Irrigation } \\
\text { Methods }\end{array}$ & $\begin{array}{c}\text { Irrigation } \\
\text { management } \\
\text { cost/fed }\end{array}$ & $\begin{array}{c}\text { Establishment } \\
\text { and } \\
\text { maintenance } \\
\text { cost/fed (LE) }\end{array}$ & $\begin{array}{c}\text { Total } \\
\text { cost/fed } \\
\text { (LE) }\end{array}$ & $\begin{array}{c}\text { Avg. } \\
\text { Yield/fed } \\
\text { (ton) }\end{array}$ & $\begin{array}{c}\text { Total } \\
\text { profit/fed } \\
\text { (LE) }\end{array}$ & $\begin{array}{c}\text { *Net } \\
\text { profit/fed } \\
\text { (LE) }\end{array}$ \\
\hline DR & 554.33 & 144.33 & 698.67 & 8.93 & 11163 & 10465 \\
\hline SR & 554.33 & 105.44 & 659.78 & 7.685 & 9606 & 8947 \\
\hline CM & 356.00 & 105.44 & 461.44 & 7.13 & 8913 & 8452 \\
\hline SS & 554.33 & 156.56 & 710.89 & 8.52 & 10650 & 9940 \\
\hline SL & 356.00 & 66.56 & 422.56 & 5.99 & 7488 & 7066 \\
\hline MBB & 554.33 & 183.22 & 737.56 & 6.76 & 8450 & 7713 \\
\hline DDL & 554.33 & 43.89 & 598.22 & 5.465 & 6831 & 6237 \\
\hline
\end{tabular}

* Reffaring to irrigation costs

Avg. ton price (LE) 1250

\section{Conclusion}

Among the modified tested irrigation methods evaluation process, potential wet-area is one of the main factors to be used in this concern. The results showed that as much as the irrigation water is well distributed around the four directions of the tree crown as much as the irrigation method was more effective and efficient. Taking these concepts into considerations, the measured parameters i.e. soil moisture, tree root distribution, tree canopy volume increments and yield; indicated that DR, SR and SS were the best among the tested treatments followed by $\mathrm{CM}$ irrigation method.

From the economic point of view the DR irrigation method ranked the first among all the others followed by SS and SR then CM and MBB ended with SL and DDL. This ranking of treatments is in harmony with that obtained by estimating the water use efficiency affecting yielding.

The modified irrigation methods can be also used in different types of soils particularly in Delta where we need to convert from the flood irrigation into new methods that increase WUE. However, it needs further investigation in this concern.

\section{References}

Alkinson, C.J., Webster, A., Vaughan, S.P., Taylor, L. and Kingswell, G. (2000) Interaction between root restriction, irrigation and rootstock treatments on "Queen Cox" apple trees: Effect of soil and plant water relations. J. Hort. \& Biotech., 75 (4), 376-382.

Allam, M.N., El Gamal, F., Hesham, M. (2005) Irrigation systems performance in Egypt. In: Lamaddalena, N. Lebdi, F. Todorovic, M. Bogliotti, C. (Ed.), pp. 85-98

Egypt. J. Hort. Vol. 40, No.2 (2013) 
Irrigation systems performance. Bari: CIHEAM. (Options Méditerranéennes : Série B. Etudes et Recherches; n . 52 )

American Soil Taxonomy (1975) Soil Taxonomy. A basic system of soil classification for making and interpreting soil surveys. Soil Conservation Survey, U.S. Dept. Agric., Hand book, 436 .

Burt, C.M. and Isbell, B. (2003) Soil salinity accumulation in orchards with drip and micro-spray irrigation in arid areas of California. ITRC Report No. R 03-005. San Luis Obispo, Cal.: California Polytechnic State University, Irrigation Training and Research Center. Available at: www.itrc.org/reports/salinity/treecropsalinity.pdf.

Carr, M.K.V. (2012) The water relations and irrigation requirements of citrus (Citrus spp.) a review. Exp. Agric., 48 (3), 347-377.

Castel, J.R. and Buj, A. (1993) Riego por goteo deficitario en naranjos adultos 'Salustiana' durante siete años. Invest Agr: Prod Prot Veg. 8(2), 191-204.

Castle, W. S. and Krezdorn, A. H (1975) Effect of citrus rootstocks on root distribution and leaf mineral content of 'Orlando' tangelo tree. J. Amer. Soc. Hort. Sci., 100,1-4.

Chartzoulakis, K., Michelakis, N. and Stefanoudaki, E. (1999) Water use, growth, yield and fruit quality of 'Bonanza' oranges under different soil water regimes. Advances in Horticultural Science, 13 (1), 6-11. (CAB International Abst. http://www.cabsubsets.com).

Croxton, Frederick Emory, Cowden, Dudley Johnstone, Klein and Sidney (1968) Applied General Statistics, Pitman. ISBN 9780273403159 (p.625)

Dariusz, S. (1992) Yield, growth, and mineral nutrition of young 'Ray Ruby' grapefruit trees under trickle or flood irrigation and various nitrogen rates. J. Amer. Soc. Hort. Sci., 117(1), 22-27.

Doorenbos, J. and Pruitt, W.O. (1977) Guidelines for predicting crop water requirements. FAO Irrigation and Drainage Paper No. 24, (revised) FAO, Rome, Italy.

Eissenstat, D.M., Whaley, E.L., Volder, A. and Wells, C.E. (1999) Recovery of citrus surface roots following prolonged exposure to dry soil. J. Expt. Bot., 50,1845-1854.

Eliades, G. (1992) Responses of grapefruit to different amounts of water applied by drippers and minisprinklers. In: Intern. Symp. Current Develop. Mediter. Trop. Subtrop. Fr. Prod. Res. Nicosia. Cyprus. 2-5 Nov., The Horticulture (1994) No. 365, 129-264. http://www.actahort.org

El-Kassas, S.E. (1972) Citrus trees responses to irrigation and fertilization. Ph. D. Thesis, Faculty of Agric., Assiut. Univ., Egypt.

Erner, Y. and Bravdo, B. (1983) The importance of inflorescence leaves in fruit setting of 'Shamouti' orange. Acta Hortic., 139, 107-113.

FAO/UN- Unknownemous (1975) Crop water requirements, irrigation and drainage. Paper No. 24, Rome.

Egypt. J. Hort. Vol. 40, No.2 (2013) 
Ford, H.W. (1968) Fluctuations of the water table in drained flatwoods groves. Proc. Fla. State Hort. Soc., 81,75-79.

Ford, H.W. (1969) Water management of wetland citrus in Florida. Proc. First Intl. Citrus Symp., 3,1759-1770.

Ford, H.W. (1972) Eight years of root injury from water table fluctuations. Proc. Fla. State Hort. Sci., 85, 65-68.

García Petillo M. (1995) Effects of irrigation periods on citrus yield and fruit quality in Uruguay. Proc Fifth Intl Microirrigation Congress. Orlando, Florida, April 2-6. pp. 492-496.

José Alves Júnior, Wije Bandaranayake, Larry R. Parsons and Adão W.P. Evangelista (2012) Citrus root distribution under water stress grown in sandy soil of central Florida. Eng. Agríc., vol.32 no.6

Kelly T. Morgan, Obreza, T.A. and Scholberg, J.M.S. (2007) Orange tree fibrous root length distribution in space and time. J. Amer. Soc. Hort. Sci., 132, 262-269

Kramer, P.J. and Boyer, J.S. (1995) Water Relations of Plants and Soils, Academic Press, N.Y.

Labanauskas, C.K., Letey, J., Stolzy L.H. and Valoras, N. (1966) Effects of soil oxygen and irrigation on the accumulation of macro-and micronutrients in citrus seedlings (Citrus sinensis var. osbeck). Soil Sci., 101, 378-384.

Legas, F.R., Lbanez, F.R., De Barreda, D.G. and Primo Millo, E. (1981) Influence of irrigation and fertilization on productivity of the Navelate Sweet orange. Intern. Cit. Cong., Tokyo, Japan, Nov., Abst. 248. (CAB International Abst. http://www.cabsubsets.com).

Lenz, F. (1966) Flower and fruit development in 'Valencia Late' orange as affected by type of inflorescence and nutritional status. Hort. Res., 6, 65-78.

Levin, I., Assaf, R. and Bravdo, B.A. (1980). Irrigation water status and nutrient uptake in apple orchard. Butterworths Borough, Green UK p. 230.

Ministry of Agriculture fertilization program for citrus (1994)

Moss, G.I., Steer, B.T. and Kriedemann, E. (1972) The regulatory role of inflorescence leaves in fruit setting by sweet orange (Citrus sinensis). Physiol. Plant., 27, 432-438.

Navarro, J.M., Pérez-Pérez, J.G., Romero, P. and Botía, P. (2010) Analysis of the changes in quality in mandarin fruit, produced by deficit irrigation treatments. Food Chemistry, 119(4), 1591-1596.

Newman, E.I. (1966) A method of estimating the total length of roots in sample. Appl. Ecol., 3,139-145.

Ray, P.K. and Sharma, B.B. (1990) Studies on response of young Kinnow trees to irrigation . Ind. J. of Hort., 47 (3), 291-296. (C.F. Hort., Abst. 65: 7368).

Egypt. J. Hort. Vol. 40, No.2 (2013) 
EVALUATION OF SOME MODIFIED FLOOD IRRIGATION METHODS ... 245

Troeh, F.R., Hobbs, J.A. and Donahue, R.L. (2004) Soil and Water Conservation for Productivity and Environmental Protection, $4^{\text {th }}$ ed. Prentice Hall. Upper Saddle River, New Jersey. p. 656.

Turell, F.M. (1965) Comparative nocturnal thermal budgets of large and small citrus trees. Ecology, 46, 25-34.

Wiegand, C.L. and Swanson, W.A. (1982 a) Citrus response to irrigation: II. Fruit yield, size and number. Journal of the Rio Grande Valley Horticultural Society, 35, 87-95.

(Received 24/7/2013 accepted 15/10/2013)

$$
\begin{aligned}
& \text { تقييم لبعض طرق الرى المعدلة على نمو وجودة ثمار أشجار } \\
& \text { البرتقال الفالنشيا تحت ظروف الأراضى الرملية } \\
& \text { رضا عبد العزيز، فاطمة قطب و مجدى عبد الفتاح }
\end{aligned}
$$

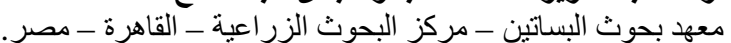

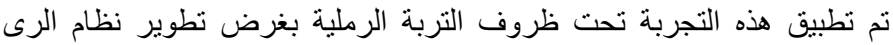

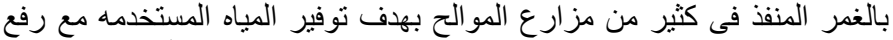

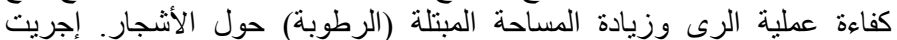

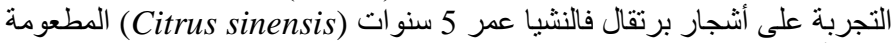

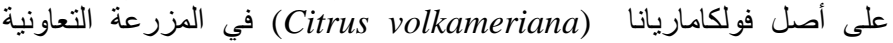

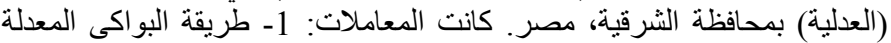

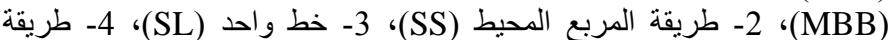

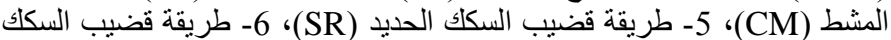

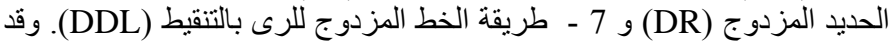

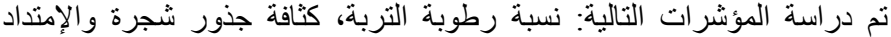

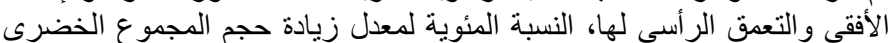

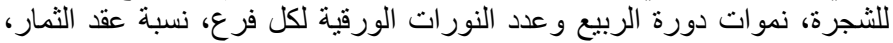
وزن الثمرة وحجم العصير، نسبة المواد الصلبة الذائبة الكلية للثمار(WSS) و التقدير الحسابى للمحصول و أخير أ كفاءة استخدام المياه (WUE).

ظظهرت النتائج أن طرق الرى التي أدت إلى زيادة كفاءة توزيع المياه

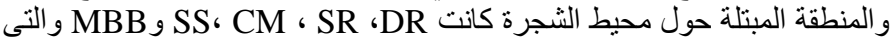
زادت من قيم كل المؤشرات تحت الدراسة باستثناء نسبة المواد الصلبة الذابة الذائبة

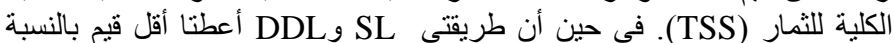
لمساحة المنطقة المبنلة. أظهرت النتائج أيضا أن كفاءة استخدام المياه (WUE) في

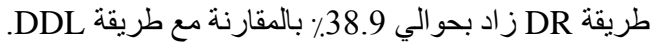

و أخير اً فمن وجهة النظر الإقتصادية فإن طريقة قضيب السكك الحديد المزدوج

للرى (DR) تم تقييمها كأفضل طريقة تلاها فى ذلك طريقة المربع المحيط (SS). 